\title{
Disentangling the Impact of the Transatlantic Slave Trade in African Diaspora Populations from a Genomic Perspective
}

\author{
Cesar A. Fortes-Lima
}

The transatlantic slave trade (TAST) was the largest forced migration in human history. Between the 15th and the 19th century, around twelve million Africans were forcibly displaced from their countries to be enslaved (that means around 30,00o captives a year over three and a half centuries). Enslaved Africans were taken from African slaving coasts that stretched thousands of miles, from Senegal to Angola, and even round the Cape and on to Mozambique (Eltis 2013). The largest number (around 95\%) of slaves arrived in Latin America, with $\sim 43 \%$ disembarked in South America, $\sim 52 \%$ in the Caribbean, while the remaining $5 \%$ arrived in what has become today the United States (Eltis and Richardson 2015). This forced and massive migration of people radically changed the genetic landscape of present-day populations in the Americas (Adhikari et al., 2017). Today African-descendant populations in the Americas seek to clarify their genetic ancestry and to better understand their genetic identity and ancestral origins (Nelson 2016).

According to historical resources, from 1501 to 1867 enslaved Africans were embarked from eight major historical coastal regions in sub-Saharan Africa: $5.7 \%$ of the captives were from Senegambia, $3.2 \%$ from Sierra Leone, $2.7 \%$ from Windward Coast, 9.6\% from Gold Coast, $16.1 \%$ from Bight of Benin, $12.3 \%$ from the Bight of Biafra, $46.3 \%$ from West Central Africa, and 4.1\% from Southeast Africa (Figure 10.1). West Central Africa region (coastal region from present-day Gabon to Angola) was always the largest regional point for captives throughout most of the TAST period, and much of the trade there was focused in present-day Angola. As the TAST expanded after 1641, slaving regions such as Gold Coast, the Bights of Benin and Biafra, and West Central Africa became more prominent than they had been before (Figure 10.1). However, there are important gaps in historical sources regarding the ancestral origin of the captives in mainland Africa. In addition, the proportions of African captives disembarked in the Americas differed remarkably among North, Central and 


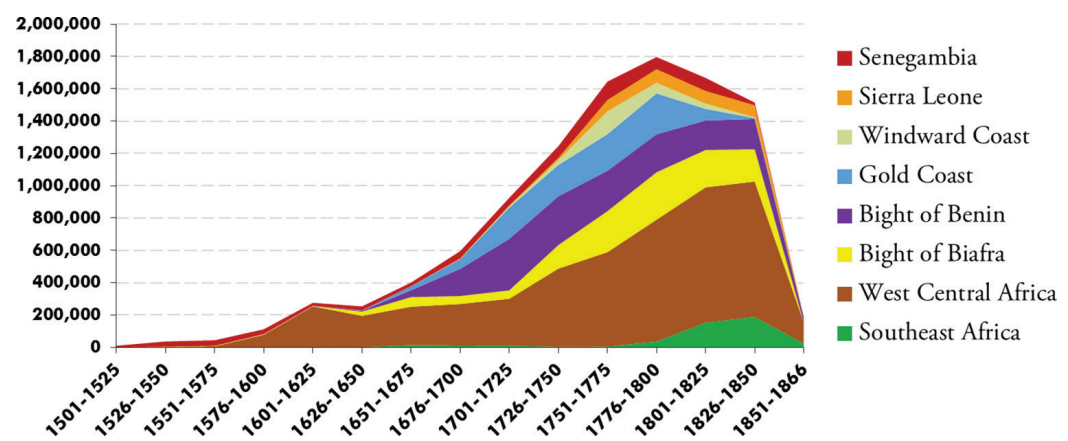

FIGURE 10.1 Estimated number of enslaved Africans disembarked in the Americas from 1501 to 1866 leaving African coastal regions REPRINTED WITH PERMISSION FROM FORTES-LIMA AND DUGOUJON 2018

especially in South America (Eltis 2013). To fill those gaps and shed new light on one of the darkest chapters in human history, recent genomic studies provide crucial information about the ancestors of African-descendant populations and their current genetic makeup.

Genome-wide studies analysing millions of genetic markers (single nucleotide polymorphisms, or SNPs) increased our understanding of the genetic heritage in African descendants, and more in particular communities established by runaway enslaved Africans during the slave trade in the Americas. One of the first genome-wide studies, authors focused on the genetic admixture of African-American groups in the United States (Bryc et al., 2010; Zakharia et al., 2009), and tried to ping-point their African ancestral origins. However, they used a limited number of African populations in their analyses, especially from western Africa. In this last decade, the development of new genome-wide methods for the production of dense genome-wide SNP data of more and more African populations, including whole-genome sequencing, have allowed us to address more complex questions about the genetic diversity in the Americas and the African Diaspora (Adhikari et al., 2017; Fortes-Lima and Dugoujon 2018). Therefore, recent studies that generated and analysed new genomic data of reference African, European and Native American populations help to gain a better understanding of the admixture history of African-descendant populations and to reconstruct trans-continental migrations.

To highlight important contributions from recent genome-wide studies, this chapter will review new insights about events that took place during and after the TAST period, the impact of this forced mass migration in the genomic diversity of African Diaspora populations, the formation of run-away communities from South America, and how genomics and paleogenomics research can unravel the history of the slave trade. 


\section{Brief Introduction about the Transatlantic Slave Trade and the} Abolitionist Movement

The TAST era is generally considered to have begun uninterrupted human traffic in 1501, when vessels crossing the Atlantic from Spain begun to carry African captives for sale in the Greater Antilles (the largest islands of the West Indies); and ended in 1867 , when the last slave vessel from Africa thought to have disembarked its captives in Cuba (Eltis and Richardson 2015). Most historians break down the slave-trade era into three main time periods that reflect the principal slave-trading nations' entry into and departure from the slave trade (Eltis et al., 2017). In the first period, the Spanish and the Portuguese established the first European empires in the Americas, with large assists from northern Italian capital and maritime expertise, they were pioneered the early slave trade. The Iberian powers dominated the trade, with Portugal and Spain being united in 1580-1640 and, in commercial terms, their separation took place in 1641 (Eltis and Richardson, 2015).

A second phase of the trade started around 1642, when the northern European nations established their own colonies in the Americas, and almost immediately began to engage in the slave trade, joined by traders from mainland North America. Before 1700, the Dutch, French, English, Danish, and Swedes systematically sent vessels to Africa to obtain captives. By the early 18th century, the slave trade systems in North and South America were firmly established. At that period, the Portuguese flag no longer had much of a presence in the slave traffic to Spanish America and the Caribbean but had the major control of the slave trade in South America, which was conducted not from Portugal but from Brazil (Eltis and Richardson, 2015). The second phase ended in 1808, when the British and the U.S. anti-slave-trade laws of 1807-1808 took effect, and other northern European nations began disengaging from the slave trade.

Anti-slavery movements ushered in the third period, which lasted through 1867 and during which abolition and suppression movements dramatically altered the pattern of participation in the slave trade. With the gradual withdrawal of the northern European powers, the TAST came to be dominated once again by the Portuguese and the Spanish, operating largely from their bases in Brazil and Cuba respectively, and against a background of growing abolitionist and suppression activities (Eltis and Richardson, 2015). Besides, the abolition of slavery in the Atlantic world occurred during the 19th century, its origins are generally recognized to be intellectual grown during the 18th century, the age of Enlightenment, with the political turmoil of the "Age of Revolution" and the economic transformations associated with the development of modern 
industrial capitalism (Inikori and Engerman 1992). The abolitionist movement started with small groups of Europeans and North Americans, who began to turn against the entrenched and lucrative business of slave trading. Later, maritime nations in Europe and North America, led by Danish and British governments, finally began legislating to ban the slave trade throughout the Atlantic world (Walvin 2013).

Although antislavery ideas circulated much more widely beginning in the 176 os, the first sustained effort to do something about slavery began in the 178 os, particularly with slave rebellions and the British campaign to end the slave trade (Walvin 2013). The Saint Domingue Revolution was a well-known slave rebellion in the French colony that broke out in 1791 and soon turned into a revolution that led to the freedom of 500,000 enslaved Africans, and ultimately to the creation of the Republic of Haiti in 1804 (Eltis et al., 2017). Consequently, the Saint Domingue Revolution closed down the biggest slave market in the Caribbean, and added a new sense of urgency to the issue in European countries and the United States. In the first decade of the 19th century, the British and the US governments abolished the slave trade in 1807. Although, the institution of slavery itself lived in the British colonies until 1838 and in the United States until 1865. Despite their efforts, over 2.5 million Africans were further transported across the Atlantic as slaves in the decades of the mid19th century (Eltis et al., 2017). During the slave trade periods, European colonies captured African people from different regions and at different periods (Figure 10.1). Therefore, present-day African Diaspora populations have complex population history and African origins due to their different European colonial past. As a result, the genomic landscape of present-day African-descendant populations in the Americas was shaped by centuries of migration, isolation, growth, selection, and admixture between recent migrants and indigenous populations.

In the USA, a former British colony, African-Americans have a complex demographic history of admixture and migration during and after the slave trade, due to mass migrations during the TAST and after during the great African-American migration that shaped the current genetic background in the USA (Baharian et al., 2016; Dai et al., 2020). In this context, recent genomewide studies have shown that African-Americans have chromosomal segments with predominantly African and European ancestries and, over the past 400 years, their admixture patterns have also changed between different 
African-American groups across the country (Baharian et al., 2016; Bryc et al., 2015; Dai et al., 2020; Han et al., 2017).

An outstanding genomic study was performed by the CAAPA Consortium, ${ }^{1}$ which analysed whole-genome sequencing data of a large number of African-descendant populations selected from North America, South America, and the Caribbean (Mathias et al., 2016). In total, 642 African descendants from fifteen American populations were sequenced to investigate admixture patterns across the Americas. Among the 328 African Americans in the United States, the authors detected a high proportion of African ancestry (on average $8 \circ \%$ ). Due to their complex history of admixture, participants from selected populations across the Americas have a large variation in their admixture patterns (ranging from $27 \%$ among Puerto Ricans to $89 \%$ among Jamaicans) (Figure 10.2), including among people who self-identify as Africandescendants. In addition, sex-biased admixture patterns were also different between groups (Mathias et al., 2016). Altogether, these results underline the erroneous vision of a homogeneous pattern of African genetic ancestry among African Diaspora populations in the Americas.

In a large-scale genome-wide study, Patin et al. (2017) estimated the demographic history and African ancestral origins of African-American populations by analysing 5,244 individuals from three large cohorts in the USA. The authors analysed the genetic diversity (around one million SNPs) of 1,033 participants from the "eMERGE" cohort from Chicago and Nashville, 1, $\mathrm{O}_{52}$ participants from the "Health $A B C$ " cohort from Memphis and Pittsburgh, and 3,159 participants from the "Multiethnic" cohort in Los Angeles. These cohorts have between $73 \%$ and $78 \%$ of African genetic ancestry (Patin et al., 2017). To more precisely trace their African genetic origin, the authors compared their African chromosomal segments with a background of 1,955 individuals from West and West-Central African populations currently living in the major historical regions of slavery. Almost $50 \%$ of their genome was estimated to come from the former region of Bight of Benin (present-day Togo, Benin and western Nigeria), 30\% from West and Central Africa (present-day Angola), 13\% from Senegambia, and $7 \%$ from the Windward Coast (Patin et al., 2017). It is interesting to note that a small amount (4.8\%) of the genetic diversity of enslaved Africans who were forced to move to the USA comes from Bantu-speaking populations from western Africa that had about $16 \%$ of rainforest hunter-gatherer (RHG) ancestry before they

1 The CAAPA Consortium studies the genomic diversity of a large number of African descendants with asthma and non-asthma selected from North America, South America, the Caribbean, and continental Africa, to represent a wide range of African ancestry. More detailed information can be found on the site (https://www.caapa-project.org). 

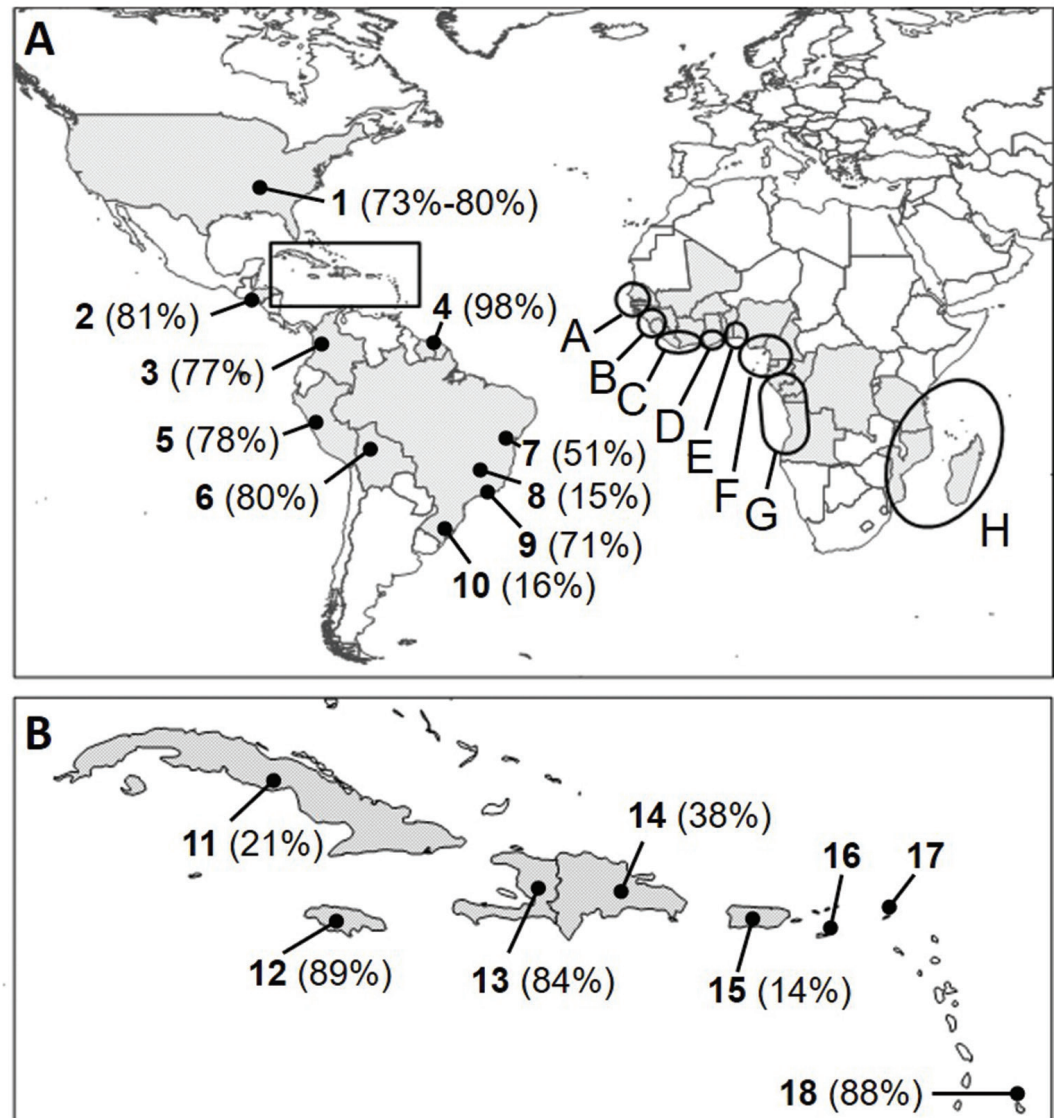

FIGURE 10.2 Geographical location of the African-descendant populations described in this chapter (and their estimated average of African ancestry in parenthesis). (A) African-descendant populations from North, Central and South America: 1- African-Americans from the United States; 2- Garifunas from Honduras; 3- African-Colombians from Chòco in Colombia; 4Noir Marron from French Guiana and Suriname; 5- African-Peruvians from Peru; 6- African-Bolivians from the Yungas Valley in Bolivia; 7-10 African-Brazilians in Brazil. (B) In detail, figure showing populations in the Caribbean: 11 Cuba; 12 Jamaica; 13 Haiti; 14 Dominican Republic; 15 Puerto Rico; 16 Sainte-Croix; 17 Saint-Martin; and 18 Barbados. Figure also shows the eight historical African regions at the time of the slave trade in Africa: A- Senegambia; B- Sierra Leone; C- Windward Coast; D- Gold Coast; E- Bight of Benin; F- Bight of Biafra; G- Central West African; and H- South-East African slave region FIGURE MODIFIED WITH PERMISSION FROM FORTES-LIMA AND DUGOUJON 2019

migrationed to the New World (Patin et al., 2017). Therefore, the genetic background and admixture dynamics of African-American groups in the United 
States are more complex than previously thought, due to the complexity of their African ancestral origins and the history of African populations before the slave trade period (Schlebusch and Jakobsson 2018). In order to better understand the genetic diversity of African Diaspora populations, it is very important to first understand the population history in the African continent.

\section{Genetic Heritage of African-Descendants in South America}

Between $15^{26}$ and 1875 , about seven million Africans were forcibly moved to South America (Eltis and Richardson 2015). During this period, enslaved Africans actively mobilized with the creation of systems of resistance against the inhuman repression that accompanied slavery. To escape captivity, a large number of slaves strongly fought against European slave systems. Between the end of 1680 and the beginning of 1712 began the phenomenon known as marronnage, characterized by massive escapes of enslaved Africans who then grouped in small and independent communities of free people, known as Maroon ${ }^{2}$ communities (Price 2013b). Currently, the cultural originality of Maroon societies is based on the preservation of their African heritage (linguistic, political, religious, or domestic traditions). Having developed their African cultures outside of European or Native American influences, and adapted them to the circumstances. Therefore, only among Maroon communities is more likely to find the most remarkable African cultural and linguistic legacies in the Americas (Price and Price 2003).

During the TAST, the system of slave resistance disrupts the functioning of slave plantations but without destabilizing them, e.g. in Honduras, Mexico, and Panama. In some cases, European settlers had resolved to approach their fugitive slaves to demand peace. They proposed treaties that granted their freedom and recognized their territorial integrity, in exchange for which they should cease all hostile acts against the plantations and refuse to help other slaves to escape. In particular regions, European colonial authorities conceded to Maroon communities the establishment of spaces enjoying official autonomy, like in Jamaica, Colombia, Surinam, and French Guiana. In a few regions,

2 The word Marron indicates fugitive slaves during the slave trade. The term, generalized in the French-speaking ("Marron") and English-speaking ("Maroon") areas, comes from the Spanish word "Cimarrón". A word borrowed from the first Amerindian inhabitants Arawak of Haiti. This word was used to designate a wild animal, or more precisely a domestic animal that has returned to wild life. While in the Spanish-Portuguese areas the common terms are "Quilombos" in Brazil, "Garifuna" in Honduras, and "Palenques" in Cuba and Colombia. 
the rebellions ended up integrating into the war of national independence, for example in Cuba and Haiti (Price 2013b).

Particularly, in Suriname (former Dutch Guiana) and French Guiana marronnage reached its peak in South America, due to in these regions the slave system experienced its major development and its maximum severity (Dupuy 2002). The punishments for fugitive slaves that were captured in Suriname were among the most brutal in the hemisphere, and included murder if they were captured for the third time (Price and Price 2003). Besides the hostility, numerous fugitive slaves from French and Dutch colonies successfully managed to escape captivity, and they were known under the names of Noir Marron or "Bushinengués" (that means "Black people in the forest", or "Bush Negroes") (Price $2013 \mathrm{~b}$ ). With an immense hinterland with this Amazon rainforest that offered a protective refuge, Noir Marron groups had the possibility to escape, to resist the repression of the European colonial masters, and some of them are still present today in isolated regions of the Amazon rainforest since the foundation of those communities (Dupuy 2002). Currently, the Noir Marron population is one of the largest and the most autonomous Maroon in the Americas (Price and Price 2003). These groups of run-away slaves organized themselves into six scattered Noir Marron communities (known as Alukus, Ndjukas, Saramakas, Paramakas, Matawai and Kwinti). Each community has their own political autonomy, cultural identity, and unique Creole languages deeply rooted in its African heritage (Price and Price 2003). As early as the 176os, certain groups signed peace treaties with the Dutch government, in particular the Ndjukas and the Saramakas, and years later with the Alukus and the Paramakas (Price 2013a). These are the four major communities of the Noir Marron population that now inhabit this region of Suriname and western French Guiana. The remaining two communities, the Matawai and the Kwinti, settled west of the Saramakas but never had a significant presence or large population sizes.

The first genetic studies that investigated the genetic history of Noir Marron communities used uniparental markers and a very limited number of autosomal markers (GM allotypes of the immunoglobulin system) (Brucato et al., 2009, 2010). Recently, within the framework of the EUROTAST European Research Network ${ }^{3}$, Fortes-Lima et al. (2017) presented the first genome-wide

3 The eurotast Research Network is a European Marie Curie Actions network for the multidisciplinary study of the transatlantic slave trade using new historical, anthropological, archaeological, and genetic approaches. In this international training network, thirteen doctoral students from different European universities and their supervisors worked in close collaboration to improve our knowledge on this subject, by including different scientific and historical perspectives. More detailed information can be found on the site (https://cordis .europa.eu/project/id/290344/reporting). 
study of the four major Noir Marron communities. The authors analysed genome-wide SNP data (around five million SNPs) of 107 African-descendants (71 Noir Marron from French Guiana and Suriname: 23 Alukus, 23 Ndjukas, 19 Saramakas, and 6 Paramakas; 16 African-Brazilians from Rio de Janeiro; and 20 African-Colombians the Chòco and Antioquia departments in Colombia). The authors compared their African genomic diversity with genome-wide SNP data of 124 individuals from West Africa (Benin, Ivory Coast, and Mali) analysed for the first time in that study, and genomic data of 2,054 African individuals obtained from previous studies.

Fortes-Lima et al. (2017) estimated a high ( 98\%) African genetic ancestry among Noir Marron communities, despite 400 years of separation from their African ancestors. In addition, these communities have high values of inbreeding coefficients, which suggest strong genetic isolation in these communities since their foundation. This exceptional African genetic heritage is one of the highest observed to date in the African Diaspora, and notably different than other African-descendants analysed in other genomic studies (Figure 10.2), e.g. Jamaicans of the CAAPA Consortium have $89 \%$ of African ancestry (Mathias et al., 2016), African-descendants from Barbados have 88\% (Martin et al., 2017), Garifuna in Saint Vincent has 70\% (Benn Torres et al., 2019), AfricanBolivians in the Yungas Valley in Bolivia have $80 \%$ (Pardo-Seco et al., 2016), and African-Peruvians have $78 \%$ (Harris et al., 2018).

Comparisons between the genetic diversity between the Noir Marron and African-descendant populations from Colombia and Brazil highlights notable differences in their admixture patterns (Figure 10.3), likely associated with their different European colonial past. While individuals of Noir Marron communities maintained a remarkably high African genetic ancestry, other Africandescendant populations have a mosaic genome with chromosomal regions of different continental ancestries with different proportions and length across the genome of individuals in each population (Figure 10.3). Besides, the African ancestry is the major ancestry in both populations (on average 70.8\% in African-Brazilians and $76.8 \%$ in African-Colombians), the admixture patterns are different between these two African-descendant populations, characterized by a high percentage of European and low Native American admixture among African-Brazilians in Rio de Janeiro (24.0\% and 5.0\%, respectively). In contrast, African-Colombians have a similar percentage of European and Native American admixture (10.7\% and $11.9 \%$, respectively).

The TAST broke familiar links between African-descendant populations and their putative African ancestors, however genomic tools can bring new information about those links (Fortes-Lima and Dugoujon 2018). Fortes-Lima et al. (2017) analyzed genome-wide SNP data to reconstruct genetic links between 

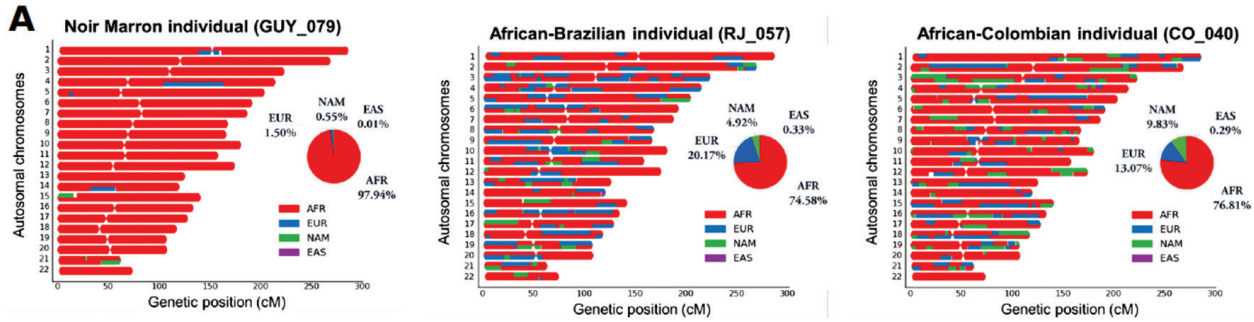

B
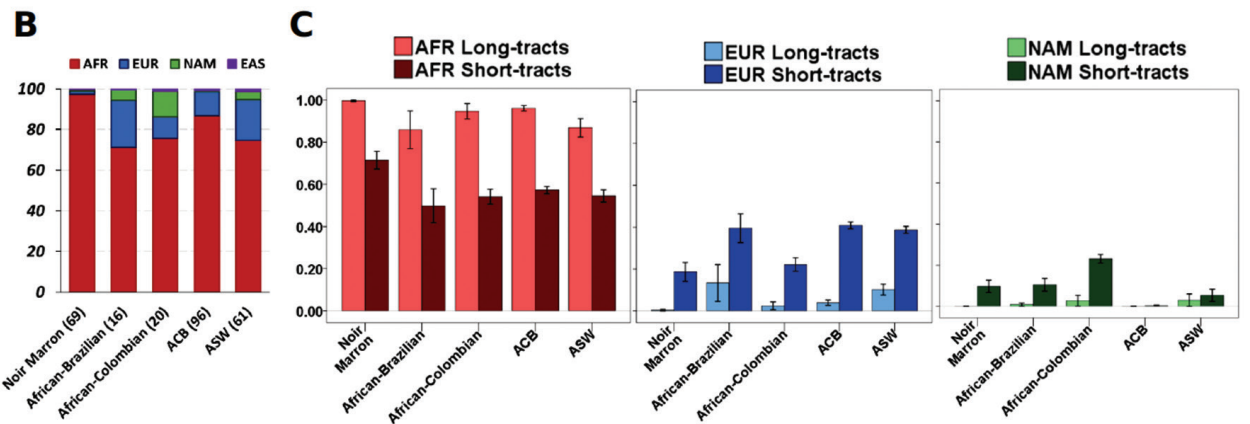

FIGURE 10.3 (A) Continental ancestries in chromosomal regions of haploid genomes in individuals from the Noir Marron, African-Brazilian and African-Colombian population. Figure showing continental ancestries estimated using a four-way admixture inference method for each individual (AFR: African ancestry represented in red; EUR: European ancestry in blue; NAM: Native American ancestry in green; and EAS: East Asian ancestry in purple).

(B) Figure showing different admixture patterns estimated in those populations, as well as African-descendant populations from Barbados and the USA (АСB and ASW, respectively). (C) Except for Noir Marron individuals, African descendants in the Americas have a mosaic genome with chromosomal regions (or ancestry tracts) of different continental ancestries and different lengths (short- and long-tracts). In particular, they have a high average of short European tracts, suggesting strong and recent European admixture FIGURE MODIFIED WITH PERMISSION FROM FORTES-LIMA ET AL., 2017

the Noir Marron communities and present-day populations from the Bight of Benin. In the ancestry-specific principal component analysis (AS-PCA), the results evidence strong genetic similarities between African haplotypes of Noir Marron individuals and populations in present-day Benin (Figure 10.4). The results were also consistent with linguistic studies based on hundreds of African words and linguistic characteristics that are commonly used by Noir Marron communities today (Essegbey et al., 2013a; Essegbey et al., 2013b; Muysken and Smith 2014). These studies revealed functional similarities with the sub-family of the Gbe linguistic family, which is spoken today by African populations from Benin (such as Fon). Therefore, genetic and linguistic studies indicate that the Bight of Benin is the most likely origin of the source population of the Noir Marron communities. 


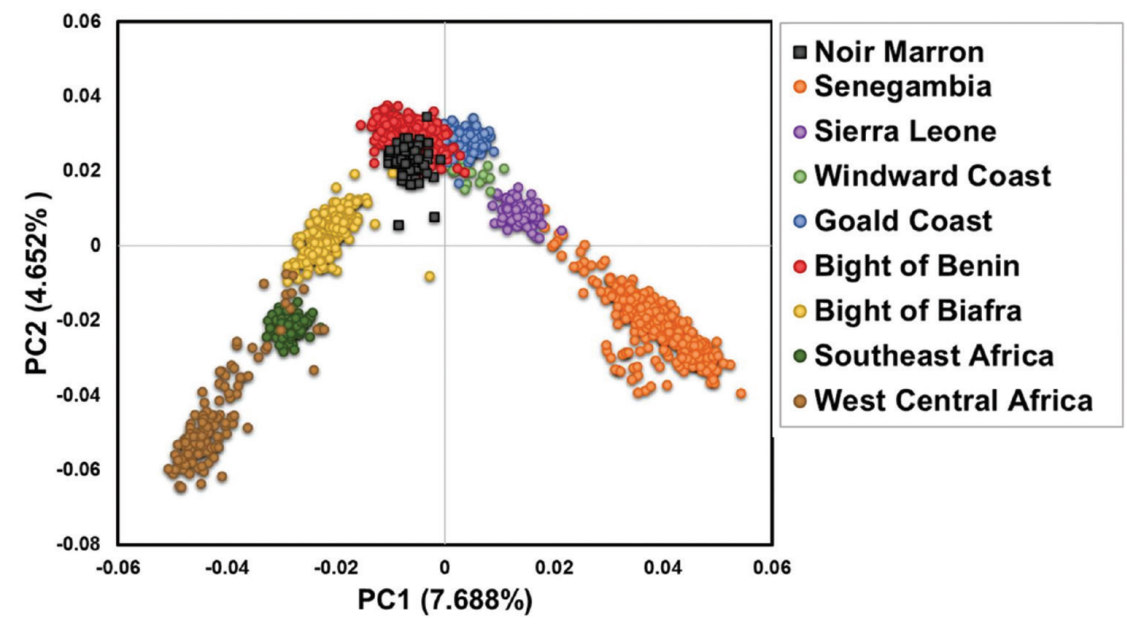

FIGURE 10.4 Ancestry-specific principal component analysis (AS-PCA) for African haplotypes of Noir Marron communities projected in a background of sub-Saharan African populations representative of the eight historical slave trade regions in Africa (described in Figure 10.2A). Figure showing strong genetic affinities between Noir Marron individuals (black squares) and African populations residing in the Bight of Benin (red dots)

FIGURE MODIFIED WITH PERMISSION FROM FORTES-LIMA ET AL., 2017

\section{Admixture Histories of African-Descendants in the Caribbean}

During the slave trade in the Caribbean colonies, some Maroon communities opposed the European colonial system and ended up into a war of national independence, like in Cuba and Haiti. Most of the genomic studies have been mainly concentrated in African-descendant populations from islands in the Greater Antilles, such as Puerto Rico (Belbin et al., 2017), Dominican Republic (Mathias et al., 2016) and Cuba (Moreno-Estrada et al., 2013). Cuba is the largest island in the Greater Antilles, and also the most populous country in the Caribbean with around 12 million inhabitants. During the TAST, around 853,000 enslaved Africans arrived in Cuba from 1526 to 1875 (Eltis and Richardson 2015). The vast majority (92\%) arrived during the last period of slavery, from 1801 to 1875 (Guanche 2011). Previous genetic studies in Cuba have provided relevant information on population history, disease resistance, and admixture dynamics (Browning et al., 2016; Moreno-Estrada et al., 2013). However, these studies analysed Cuban participants residing in the USA for a few generations.

By analysing over 1,00o individuals born and living today in the fifteen provinces of Cuba, Marcheco-Teruel et al. (2014) carried out a comprehensive study 
of this large sample size by using uniparental markers and 128 ancestry informative markers (AIMs). This large number of individuals born in Cuba is a very good representation of the current distribution of the population in terms of sex, age, and population density (Roblejo and Marcheco-Teruel 2017). To investigate the population structure and the demographic history in Cuba, more recently Fortes-Lima et al. (2018) analysed genome-wide SNP data (around 600,000 SNPs) of 86o participants sampled previously by Marcheco-Teruel et al. (2014). The results showed a fine-scale population structure within Cuba and variable admixture profiles between the Cuban provinces. On average, the proportion of European ancestry estimated in all of the studied Cuban samples was notably high $(71 \%)$, with the highest values among western Cuban provinces, such as Mayabeque (87.7\%). On the other hand, the results showed high levels of African ancestry among participants from eastern Cuban provinces, such as Santiago de Cuba (38.8\%) and Guantanamo (40.1\%). Interestingly, western Cuban participants in Havana have also important proportions of African genetic ancestry ( 27.9\%). In the eastern Cuban provinces, individuals have also relatively high Native American ancestry (like in Holguin with $10.6 \%$, Granma with $12.4 \%$, and Las Tunas with $13.9 \%$ on average). In agreement, in those provinces is where there is the highest concentration of Taíno archaeological sites (Dominguez 2014).

To study the African ancestral origin in the Cuban population, the authors used an African reference panel of 45 sub-Saharan African populations. Using haplotype-based analyses, the authors estimated strong genetic affinities between the haplotypes of the Cuban population with African ancestry and the haplotypes of African populations originally from the historical slave regions of Bight of Benin, Bight of Biafra, and West Central Africa (Fortes-Lima et al., 2018). Interestingly, the genomic results were in accordance with historical sources that highlight these regions were the three main sources of enslaved Africans who arrived in Cuba (representing $70 \%$ of the slave population) (Guanche 2011, Eltis and Richardson 2015). Further, the highest proportions of African admixture were observed in the municipalities of the provinces of Havana and Santiago de Cuba. These provinces were respectively the first- and second-largest ports of slaves during the slave trade in Cuba. From 1551 to 1875, more than 350,00o enslaved Africans arrived in Havana ( $41 \%$ of the total slave population) (Eltis and Richardson 2015). In the rest of the island, especially in the eastern region, the slave trade was less intensive and later, e.g. in Santiago de Cuba more than 55,00o enslaved Africans arrived from 1701 to $1875(6.5 \%$ of the total slave population) (Eltis and Richardson 2015).

To reconstruct recent histories of admixture, different scenarios of admixture events were modelled in the three main historical regions in Cuba (western, central, and eastern Cuba). In agreement with Marcheco-Teruel et al. (2014), 
the models of the geographic admixture observed comply with archaeological and historical sources (Guanche 2011). In the western and central regions, the results show dates of early admixture for the first African and Native American admixture event (14-15 generations ago in both regions), while a second African and Native American admixture event was estimated much later (3-4 and 7-8 generations ago, respectively). The inferred model (the tested model with the "best" fitting parameters) showed stronger African ancestry in the eastern provinces of Cuba, which is consistent with the admixture proportions estimated in Santiago de Cuba and Guantanamo using different genome-wide methods (39\% and $40 \%$, respectively). Interestingly, these eastern provinces have a higher frequency of long chromosomal segments of African ancestry (on average $41 \%$ ) than the other provinces (on average $14 \%$ ), suggesting a more recent and strong African gene-flow in the eastern Cuba region that post-date the TAST (after the abolition of the slave trade) (Fortes-Lima et al., 2018).

The results were in line with intra-continental migrations within the Caribbean rather than with trans-continental migrations from Africa to the Americas. In agreement, a significant mass migration took place from Haiti to Cuba. Between 1913 and 1931, legal migration from Haiti to Cuba was estimated at more than 189,000 migrants, while illegal migration was estimated from 450,000 to 60o,00o (Guanche 2011). The Haitian population has one of the highest of African ancestry in the Caribbean ( $84 \%$ on average) (Moreno-Estrada et al., 2013), in contrast with the Garifuna community in Saint Vincent that is a well-known Maroon community in the Caribbean, which has $70 \%$ of African ancestry (Benn Torres et al., 2019). The estimated admixture dates likely reflect recent events of African migration (3-4 generations ago) that are particularly high in the eastern Cuban region. Therefore, Cuba has experienced major mass migrations involving multiple indigenous and European groups, as well as African migrants due to trans-continental forced migration in the Atlantic world during the TAST, and more recently large-scale intra-continental movements in the Caribbean after the abolition of the slave trade likely from Haitian labour workers. For that reason it is important that researchers ensure an appropriate representation of individuals from different Cuban regions in future biomedical and genomic studies (Roblejo and Marcheco-Teruel 2017).

\section{Paleogenomics Studies in the Context of the Transatlantic Slave Trade}

Due to the high temperature and humidity, one would expect not to find traces of ancient DNA (aDNA) in the Caribbean. Nonetheless, Schroeder et al. (2015) successfully generated genomic data of three enslaved Africans from the $17^{\text {th }}$ 
century to study their individual genetic histories, as part of the EUROTAST research network. Those human remains about 400 years old were accidentally found in 2010 in a cemetery, in the Zoutsteeg region of Philipsburg, on the Antillean Island of Saint Martin (Figure 10.2B), in the area which was colonized by the Dutch government. They are known as the "Zoutsteeg Three" and were identified two as men and one as a woman. They were found together with artifacts dating from the 17th century, osteo-archaeological analysis indicated that they were between 25 and 40 years old when they died. Radiocarbon dating indicated they were buried between 166o and 1688 (Schroeder et al., 2015). Interestingly, their teeth had been deliberately chipped and cut into points and other shapes, suggesting that they were apparently not born in Saint-Martin, because that is a foreign cultural practice in the Caribbean more commonly practised in sub-Saharan Africa (Jones 1992). Together, their dental modifications and isotopes analysis strongly suggested that they were born somewhere in Africa and most likely brought by force to Saint Martin to work as slaves on sugar plantations (Schroeder, Haviser, and Price 2014).

From small bits in the dental roots of three enslaved Africans, the Zoutsteeg Three, Schroeder et al. (2015) successfully generated human nuclear and mitochondrial DNA data using whole-genome capture methods to enrich human DNA content in sets of aDNA libraries (Carpenter et al., 2013). In addition, the estimated modern DNA contamination was very low $(<1 \%)$. To trace their African origins, the authors compared ancient genomes with those of eleven modern populations in West Africa, and found genetic affinities with at least two distinct linguistic groups. Thus, besides these three individuals were buried together, they may not have had a language in common. One of the men probably belonged to Bantu-speaking populations residing in Congo and Cameroon, while the other man and the woman most probably belonged to non-Bantu-speaking populations from present-day Nigeria or Ghana (Schroeder et al., 2015). Their different African ancestral origin underlines that enslaved Africans from the same plantations likely lived together with other captives speaking different languages and belonging to different ethno-linguistic groups. Nonetheless, it is possible that the genomes of the closest genetic ancestors of to the Zoutsteeg Three have not been analysed yet, and future analyses would require to increase the number of reference African populations to have more comprehensive information.

In another outstanding paleogenomics study, Barquera et al. (2020) analysed human remains of enslaved Africans buried in a mass burial in Mexico City. To better understand the lives and health status of enslaved Africans in Mexico colonial, the authors performed comprehensive analyses of those remains using a multi-disciplinary approach that combined bioarchaeological, 
osteological, isotopic, and genome-wide analysis of three individuals (named as SJNoo1, SJNoo2 and SJNoo3). Bioarchaeological analysis of their remains evidenced dental modification patterns that are culturally associated with a sub-Saharan African origin. Those three individuals were genetically identified as males, and radiocarbon dating analysis suggested that the individuals died shortly after the beginning of the colonial period in Mexico City $\left({ }^{14} \mathrm{C}\right.$ dating: AD 1436-1626). Together, the results highlighted these individuals were likely the first-generation enslaved Africans who died very early during the colonial period in Mexico (Barquera et al., 2020).

However, the lives of the first-generation enslaved Africans in Mexico were remarkably hurtful. Osteological analyses revealed a life experience of conflict and hardship in the three individuals. Individual SJNoor was found with two healing needles in the thoracic cavity and gunshot wounds. In addition, both SJNoo1 and SJNoo3 presented pathological changes such as "cribra orbitalia" (Barquera et al., 2020), which is generally associated with a skeletal response to nutritionally inadequate diets, anaemia, parasitic infectious diseases, and blood loss (Walker et al., 2009). Individual SJNoo2 displayed several skeletal changes associated with intense labour and heavy manual activity, including deformations on the clavicle and scapula. Additionally, he suffered from a poorly aligned complete fracture in the right fibula and tibia, resulting in associated joint changes of the knee and deformation (Barquera et al., 2020).

The dental modification patterns by mechanical modifications are consistent with cultural practices previously reported for enslaved Africans from different contexts (Wasterlain, Neves, and Ferreira 2016), but also observed in groups living in coastal Western African regions today (Jones 1992). Both uniparental markers of these individuals were associated with sub-Saharan African mitochondrial haplogroups (L1b, L3d and L3e1) and Y-chromosome haplogroups (E3bia and E-M2 for the three individuals). In addition, HLA allelic variation of the three individuals is highlighting a sub-Saharan African origin (Barquera et al., 2020). They have similar HLA haplotypes that the haplotypes previously reported in sub-Saharan African populations (Arlehamn et al., 2017). To further assess the origin of these ancient individuals, the authors carried out strontium analysis on the molars of each individual, which forms early during childhood and thus is a good proxy for place of birth. The strontium ratio values are above 0.7107 for or the three studied individuals (Barquera et al., 2020), which are the highest values recorded in the central part of Mexico (range: 0.7045-0.7052) and Mexico City (range: 0.7062-0.7064) (Price et al., 2012; Juarez 2008). In fact, those values are consistent with a West African origin estimated for enslaved Africans in Barbados (range: 0.7060-0.7414) (Schroeder et al., 2009). 
The three individuals were buried in a mass grave in the grounds located just outside of the hospital that contained skeletal remains of several individuals disposed in layers, which is consistent with burials made during epidemics. By using genetic tools, researchers can screen ancient individuals to look for potential pathogenic agents using novel bioinformatic approaches to search and filter reads from the genomic libraries (Hübler et al., 2019). Barquera et al. (2020) used this approach to sequence reads from ancient remains (tooth dentine powder) that were mapped to bacteria genomes, which could either be part of the oral microbiota or implicated in taphonomic processes. Apart from environmental bacteria, interestingly over 50 reads were mapped specifically to Treponema pallidum genomes in individual SJNoo3, which is a positive evidence of treponemal infection (Barquera et al., 2020). Further, eight sequenced reads mapped specifically to hepatitis B virus (HBV) DNA in individual SJNoor. Phylogenetic analysis confirmed that SJNoo1 HBV belonged to sub-genotype A3, which is typically found in West Africa (Pourkarim et al., 2014; Andernach et al., 2009). A maximum-likelihood tree of Treponema strains showed the SJNoo3 genome clustered within the Treponema pallidum subsp. pertenue (TPE), which is the causative agent of yaws, and phylogenetically associated with strains isolated from patients in Western Africa (Barquera et al., 2020). Overall, paleogenomics analyses of enslaved Africans in the Americas further increase our understanding of the genetic history of these enslaved Africans and their ancestral African origins. These findings demonstrate that aDNA methods together with other approaches can successfully be used to trace the putative ancestors, infer the living conditions of populations in the Americas from the first-generation of enslaved African until present-day African descendants, and provide new findings that have important implications in archaeology and biological anthropology, especially in cases where historical information about the TAST is missing.

Since written histories about the lives and enslavement of the ancestors of African descendants are scant, archaeological data becomes invaluable. However, archaeologists often struggle with the challenge of linking historic-period artifact assemblages with specific communities. By using another interesting approach, Jagadeesan et al. (2018) carried out a virtual reconstruction of aDNA of the African genome of one enslaved African born in the 18th century (1784) on Saint Croix island (one of the U.S. Virgin islands) (Figure 10.2B). Within the framework of the EUROTAST research network, the authors carried out a "virtual" aDNA study without using (or destroying) this person's biological material (such as bones or hair), whose name was Hans Jonatan (Palsson 2016). The genetic information obtained from current descendants of this man (who are part of the Islandic population) was used to reconstruct chromosomal 
fragments of his African genetic ancestry. This information was used to first reconstruct the maternal part of the genome of Hans Jonatan, and then to determine that his mother was originally from the historic regions of the Bights of Benin and Biafra (Jagadeesan et al., 2018). This study therefore shows that the use of genealogical and genomic data can largely reconstruct, in certain specific populations, the genome of the putative ancestors of enslaved Africans, without having direct access to ancient remains for the study.

Today, through aDNA analysis is also possible to recover aspects of people's lives that were once thought unknowable, and hold the potential to connect living descendants with their putative ancestors. Future paleogenomics studies will retrieve aDNA from human remains as well as personal artifacts of enslaved Africans found in historic plantations, like tobacco pipes. The study presented by Schablitsky et al. (2019) is a great example of this cross-disciplinary research. First, the authors successfully extracted aDNA from a clay tobacco pipe stem collected from an African-American slave quarter in Maryland (USA), where generations of enslaved Africans lived and worked on tobacco plantations between 1736 and 1864. The owner of that tobacco pipe was genetically identified as a woman. Then, genome-wide analyses revealed she was closely related to Mende-speaking people living in present-day Sierra Leone (former Sierra Leone slave coastal region). Therefore, paleogenomics research provides archaeologists with novel tools to address questions about African-American communities and their African ancestral origins.

Conclusions and Future Directions

These stories of complex admixture in America, during and after the slave trade, had a great influence on genetic diversity. In this chapter, through a few examples, I seek to review the latest studies that combine historical factors and genetic history. With the new genomic data available today, it is possible to more accurately determine ancestral origins and also to better specify the influence of triangular trade on the various histories of interbreeding in African-descendant populations in the Americas. In this context, recent genomic research unravels the impact of demographic events associated with complex admixture events, as well as ancestral origins with unprecedented geographic resolution. In future studies, researchers will apply new statistical methods to further test complex events of admixture in African-descendant populations and reconstruct demographic histories across the Americas of populations that had undergone the TAST (Fortes-Lima et al., 2021). 
Ancient DNA studies of human remains have painted a more complete picture of the living conditions of enslaved Africans during the transatlantic slave trade, e.g. for the Zoutsteeg Three in Saint Martin and the first-generation enslaved Africans in Mexico. Furthermore, aDNA studies have shown that ancient and modern DNA can help us to reconstruct family histories and historical movements of populations by retrieving aDNA from human remains, present-day African descendants or personal artifacts of enslaved Africans found in historic plantations.

Altogether, genome-wide studies of both ancient and present-day populations in Africa and the Americas present valuable information about the slave trade that can complement fragmented historical sources (Fortes-Lima et al., 2017; Patin et al., 2017). In this context, recent findings presented in genomic studies have made possible to draw conclusions on the continental and sub-continental ancestral origins and genetic history of African and African-descendant populations at each side of the Atlantic.

\section{Acknowledgements}

C.F-L. would like to thank Jean-Michel Dugoujon, Hannes Schroeder, Paul Verdu, and Esteban Parra for helpful discussions. C.F-L. was funded in part by the eurotast Marie Curie Initial Training Network (grant number: MC-ITN 290344), the French "Agence Nationale pour la Recherche" (ANR) grant METHIS (grant number: ANR-15-CE32-ooo9-o1), and by the Sven and Lilly Lawski's Foundation (postdoc scholarship; grant number: N2019-0040).

\section{References}

Adhikari, K., Chacón-Duque, J.C., Mendoza-Revilla, J., Fuentes-Guajardo, M., and Ruiz-Linares, A. 2017. The Genetic Diversity of the Americas. Annual Review of Genomics and Human Genetics 18: 277-296. https://doi.org/10.1146/annurev-ger nom-083115-022331.

Andernach, I.E., Nolte, C., Pape, J.W., and Muller, C.P. 20og. Slave trade and hepatitis B virus genotypes and subgenotypes in Haiti and Africa. Emerging Infectious Diseases 15(8): 1222-1228. https://doi.org/10.3201/eid1508.081642.

Arlehamn, C.S.L., Copin, R., Leary, S., Mack, S.J., Phillips, E., Mallal, S., Sette, A., Blatner, G., Siefers, H., Ernst, J.D., and TBRU-ASTRa Study Team. 2017. Sequence-based HLAA, B, C, DP, DQ, and DR typing of 100 Luo infants from the Boro area of Nyanza Province, Kenya. Human Immunology 78(4): 325-326. https://doi.org/10.1016/ j.humimm.2017.03.007. 
Baharian, S., Barakatt, M., Gignoux, C.R., Shringarpure, S., Errington, J., Blot, W.J., Bustamante, C.D., Kenny, E.E., Williams, S.M., Aldrich, M.C., and Gravel, S. 2016. The Great Migration and African-American genomic diversity. PLoS Genetics 12(5): e1006o59. https://doi.org/10.1371/journal.pgen.1006o59.

Barquera, R., Lamnidis, T.C., Lankapalli, A.K., Kocher, A., Hernández-Zaragoza, D.I., Nelson, E.A., Zamora-Herrera, A.C., Ramallo, P., Bernal-Felipe, N., Immel, A., Bos, K., Acuña-Alonzo, V., Barbieri, C., Roberts, P., Herbig, A., Kühnert, D., MárquezMorfín, L., and Krause, J. 202O. Origin and health status of first-generation Africans from early colonial Mexico. Current Biology 3o(11): 2078-2091.e11. https://doi .org/10.1016/j.cub.2020.04.002.

Belbin, G.M., Odgis, J., Sorokin, E.P., Yee, M.-C., Kohli, S., Glicksberg, B.S., Gignoux, C.R., Wojcik, G.L., Van Vleck, T., Jeff, J.M., Linderman, M., Schurmann, C., Ruderfer, D., Cai, X., Merkelson, A., Justice, A.E., Young, K.L., Graff, M., North, K.E., Peters, U., James, R., Hindorff, L., Kornreich, R., Edelmann, L., Gottesman, O., Stahl, E.E., Cho, J.H., Loos, R.J., Bottinger, E.P., Nadkarni, G.N., Abul-Husn, N.S., and Kenny, E.E. 2017. Genetic identification of a common collagen disease in Puerto Ricans via identity-by-descent mapping in a health system. eLife 6: e2506o. https://doi.org/10.7554/eLife.25o6o.

Benn Torres, J., Martucci, V., Aldrich, M.C., Vilar, M.G., MacKinney, T., Tariq, M., Gaieski, J.B., Bharath Hernandez, R., Browne, Z.E., Stevenson, M., Walters, W., Schurr, T.G., and Genographic Consortium 2019. Analysis of biogeographic ancestry reveals complex genetic histories for indigenous communities of St. Vincent and Trinidad. American Journal of Physical Anthropology 169(3): 482-497. https://doi.org/10.1002/ ajpa.23859.

Browning, S., Grinde, K., Plantinga, A., Gogarten, S.M., Stilp, A.M., Kaplan, R.C., AvilésSanta, M.L., Browning, B.L., and Laurie, C.C. 2016. Local Ancestry Inference in a Large US-Based Hispanic/Latino Study: Hispanic Community Health Study/Study of Latinos (HCHS/sOL). G3 6(6): 1525-1534. https://doi.org/10.1534/g3.116.o28779.

Brucato, N., Cassar, O., Tonasso, L., Tortevoye, P., Migot-Nabias, F., Plancoulaine, S., Guitard, E., Larrouy, G., Gessain, A., and Dugoujon, J.-M. 2010. The imprint of the Slave Trade in an African American population: mitochondrial DNA, Y chromosome and HTLV-1 analysis in the Noir Marron of French Guiana. BMC Evolutionary Biology 10: 314. https://doi.org/10.1186/1471-2148-10-314.

Brucato, N., Tortevoye, P., Plancoulaine, S., Guitard, E., Sanchez-Mazas, A., Larrouy, G., Gessain, A., and Dugoujon, J.-M. 20og. The genetic diversity of three peculiar populations descending from the slave trade: Gm study of Noir Marron from French Guiana. Comptes Rendus Biologies 332(10): 917-926. https://doi.org/10.1016/j.crvi.2009.07.005. Bryc, K., Auton, A., Nelson, M.R., Oksenberg, J.R., Hauser, S.L., Williams, S., Froment, A., Bodo, J.-M., Wambebe, C., Tishkoff, S.A., and Bustamante, C.D. 2010. Genomewide patterns of population structure and admixture in West Africans and African Americans. Proceedings of the National Academy of Sciences of the USA 107(2): 786791. https://doi.org/10.1073/pnas.o9o9559107. 
Bryc, K., Durand, E.Y., Macpherson, J.M., Reich, D., and Mountain, J.L. 2015. The genetic ancestry of African Americans, Latinos, and European Americans across the United States. American Journal of Human Genetics 96(1): 37-53. https://doi.org/10.1016/ j.ajhg.2014.11.o10.

Carpenter, M.L., Buenrostro, J.D., Valdiosera, C., Schroeder, H., Allentoft, M.E., Sikora, M., Rasmussen, M., Gravel, S., Guillén, S., Nekhrizov, G., Leshtakov, K., Dimitrova, D., Theodossiev, N., Pettener, D., Luiselli, D., Sandoval, K., Moreno-Estrada, A., Li, Y., Wang, J., Gilbert, M.T.P., Willerslev, E., Greenleaf, W.J., and Bustamante, C.D. 2013. Pulling out the $1 \%$ : whole-genome capture for the targeted enrichment of ancient DNA sequencing libraries. American Journal of Human Genetics 93(5): 852-864. https://doi.org/10.1016/j.ajhg.2013.10.002.

Dai, C.L., Vazifeh, M.M., Yeang, C.-H., Tachet, R., Wells, R.S., Vilar, M.G., Daly, M.J., Ratti, C., and Martin, A.R. 202O. Population Histories of the United States Revealed through Fine-Scale Migration and Haplotype Analysis. American Journal of Human Genetics 106(3): 371-388. https://doi.org/10.1016/j.ajhg.2020.02.002.

Dominguez, L.S. 2014. L'esclavage colonial à Cuba : les données de l'archéologie. In: Delpuech, A., and Jacob, J.P. (eds) Archéologie de l'esclavage colonial. Éditions La Découverte: Ivry-sur-Seine Cedex, France, pp. 171-182.

Dupuy, F. 2002. Des esclaves marrons aux Bushinenge : le marronnage et ses suites dans la région des Guyanes. Cahiers d'histoire. Revue d'histoire critique 89: 29-39.

Eltis, D. 2013. Routes to Slavery: Direction, Ethnicity and Mortality in the Transatlantic Slave Trade. Routledge: Oxfordshire, UK.

Eltis, D., Engerman, S.L., Drescher, S., and Richardson, D. 2017. The Cambridge World History of Slavery: Volume 4, $A D$ 1804-AD 2016. Cambridge University Press: Cambridge, UK.

Eltis, D., and Richardson, D. 2015. Atlas of the Transatlantic Slave Trade. Yale University Press: Connecticut, USA.

Essegbey, J., van den Berg, M., and van de Vate, M. 2013a. Possibility and necessity modals in Gbe and Surinamese creoles. Lingua. International Review of General Linguistics. Revue Internationale de Linguistique Generale 129: 67-95.

Essegbey, J., Migge, B., and Winford, D. 2013b. Cross-linguistic influence in language creation: Assessing the role of the Gbe languages in the formation of the Creoles of Suriname. Lingua. International Review of General Linguistics. Revue Internationale de Linguistique Generale 129: 1-8.

Fortes-Lima, C., Bybjerg-Grauholm, J., Marin-Padrón, L.C., Gomez-Cabezas, E.J., Bækvad-Hansen, M., Hansen, C.S., Le, P., Hougaard, D.M., Verdu, P., Mors, O., Parra, E.J., and Marcheco-Teruel, B. 2018. Exploring Cuba's population structure and demographic history using genome-wide data. Scientific Reports 8(1): 11422. 
Fortes-Lima, C., and Dugoujon, J.-M. 2018. Revisiting genetic ancestry in African Diaspora communities from Atlantic South America. In: Holst, M., and Alexander, M. (eds) Trends in Biological Anthropology Volume 2. Oxbow Books: Oxford, UK, pp. 9-17.

Fortes-Lima, C., and Dugoujon, J.-M. 2019. La diaspora africaine dans les Amériques : l'apport des nouvelles approches génomiques pour illustrer l'héritage génétique des descendants africains dans le contexte de la traite négrière transatlantique. In Costedoat, C., and Mazières, S. (eds) Corps - Os, sangs, gènes et cultures. Volume 17. CNRs Éditions: Paris, France, pp. 175-186.

Fortes-Lima, C., Gessain, A., Ruiz-Linares, A., Bortolini, M.-C., Migot-Nabias, F., Bellis, G., Moreno-Mayar, J.V., Restrepo, B.N., Rojas, W., Avendaño-Tamayo, E., Bedoya, G., Orlando, L., Salas, A., Helgason, A., Gilbert, M.T.P., Sikora, M., Schroeder, H., and Dugoujon, J.-M. 2017. Genome-wide Ancestry and Demographic History of African-Descendant Maroon Communities from French Guiana and Suriname. American Journal of Human Genetics 101(5): 725-736. https://doi.org/10.1016/j.ajhg.2017.09.021.

Fortes-Lima, C., Laurent, R., Thouzeau, V., Toupance, B., and Verdu, P. 2021. Complex genetic admixture histories reconstructed with Approximate Bayesian Computations. Molecular Ecology Resources 21(4): 1098-1117. doi: 10.1111/1755-0998.13325.

Guanche, J. 2011. Componentes étnicos de la nación cubana. Editorial Ciencias Sociales: La Habana, Cuba.

Han, E., Carbonetto, P., Curtis, R.E., Wang, Y., Granka, J.M., Byrnes, J., Noto, K., Kermany, A.R., Myres, N.M., Barber, M.J., Rand, K.A., Song, S., Roman, T., Battat, E., Elyashiv, E., Guturu, H., Hong, E.L., Chahine, K.G., and Ball, C.A. 2017. Clustering of 770,000 genomes reveals post-colonial population structure of North America. Nature Communications 8: 14238. https://doi.org/10.1038/ncomms14238.

Harris, D.N., Song, W., Shetty, A.C., Levano, K.S., Cáceres, O., Padilla, C., Borda, V., Tarazona, D., Trujillo, O., Sanchez, C., Kessler, M.D., Galarza, M., Capristano, S., Montejo, H., Flores-Villanueva, P.O., Tarazona-Santos, E., O'Connor, T.D., and Guio, H. 2018. Evolutionary genomic dynamics of Peruvians before, during, and after the Inca Empire. Proceedings of the National Academy of Sciences of the USA 115: E6526E6535. https://doi.org/10.1073/pnas.1720798115.

Hübler, R., Key, F.M., Warinner, C., Bos, K.I., Krause, J., and Herbig, A. 2019. HOPS: automated detection and authentication of pathogen DNA in archaeological remains. Genome Biology 20(1): 28o. https://doi.org/10.1186/s13059-019-1903-0.

Inikori, J.E., and Engerman, S.L. 1992. The Atlantic Slave Trade: Effects on Economies, Societies and Peoples in Africa, the Americas, and Europe. Duke University Press: North Carolina, USA. 
Jagadeesan, A., Gunnarsdóttir, E.D., Ebenesersdóttir, S.S., Guðmundsdóttir, V.B., Thordardottir, E.L., Einarsdóttir, M.S., Jónsson, H., Dugoujon, J.-M., Fortes-Lima, C., Migot-Nabias, F., Massougbodji, A., Bellis, G., Pereira, L., Másson, G., Kong, A., Stefánsson, K., and Helgason, A. 2018. Reconstructing an African haploid genome from the 18th century. Nature Genetics 50(2): 199-205. https://doi.org/10.1038/ s41588-017-0o31-6.

Jones, A. 1992. Tooth mutilation in Angola. British DentalJournal 173(5):177-179. https:// doi.org/10.1038/sj.bdj.4807989.

Juarez, C.A. 2008. Strontium and geolocation, the pathway to identification for deceased undocumented Mexican border-crossers: A preliminary report. Journal of Forensic Sciences 53(1): 46-49. https://doi.org/10.1111/j.1556-4029.2007.00610.x

Marcheco-Teruel, B., Parra, E.J., Fuentes-Smith, E., Salas, A., Buttenschøn, H.N., Demontis, D., Torres-Español, M., Marín-Padrón, L.C., Gómez-Cabezas, E.J., Alvarez-Iglesias, V., Mosquera-Miguel, A., Martínez-Fuentes, A., Carracedo, A., Børglum, A.D., and Mors, O. 2014. Cuba: exploring the history of admixture and the genetic basis of pigmentation using autosomal and uniparental markers. PLoS Genetics 10(7): e1004488. https://doi.org/10.1371/journal.pgen.1004488.

Mathias, R.A., Taub, M.A., Gignoux, C.R., Fu, W., Musharoff, S., O'Connor, T.D., Vergara, C., Torgerson, D.G., Pino-Yanes, M., Shringarpure, S.S., Huang, L., Rafaels, N., Boorgula, M.P., Johnston, H.R., Ortega, V.E., Levin, A.M., Song, W., Torres, R., Padhukasahasram, B., Eng, C., Mejia-Mejia, D.-A., Ferguson, T., Qin, Z.S., Scott, A.F., Yazdanbakhsh, M., Wilson, J.G., Marrugo, J., Lange, L.A., Kumar, R., Avila, P.C., Williams, L.K., Watson, H., Ware, L.B., Olopade, C., Olopade, O., Oliveira, R., Ober, C., Nicolae, D.L., Meyers, D., Mayorga, A., Knight-Madden, J., Hartert, T., Hansel, N.N., Foreman, M.G., Ford, J.G., Faruque, M.U., Dunston, G.M., Caraballo, L., Burchard, E.G., Bleecker, E., Araujo, M.I., Herrera-Paz, E.F., Gietzen, K., Grus, W.E., Bamshad, M., Bustamante, C.D., Kenny, E.E., Hernandez, R.D., Beaty, T.H., Ruczinski, I., Akey, J., CAAPA and Barnes, K.C. 2016. A continuum of admixture in the Western Hemisphere revealed by the African Diaspora genome. Nature Communications 7: 12522. https://doi.org/10.1038/ncomms12522.

Moreno-Estrada, A., Gravel, S., Zakharia, F., McCauley, J.L., Byrnes, J.K., Gignoux, C.R., Ortiz-Tello, P.A., Martínez, R.J., Hedges, D.J., Morris, R.W., Eng, C., Sandoval, K., Acevedo-Acevedo, S., Norman, P.J., Layrisse, Z., Parham, P., Martínez-Cruzado, J.C., Burchard, E.G., Cuccaro, M.L., Martin, E.R., and Bustamante, C.D. 2013. Reconstructing the population genetic history of the Caribbean. PLoS Genetics 9(11): e1003925. https://doi.org/10.1371/journal.pgen.1003925.

Muysken, P.C., and Smith, N. 2014. Surviving the Middle Passage: The West Africa-Surinam Sprachbund. Walter de Gruyter GmbH \& Co KG: Berlin, Germany.

Nelson, A. 2016. The Social Life of DNA: Race, Reparations, and Reconciliation After the Genome. Beacon Press: Boston, USA. 
Palsson, G. 2016. The Man Who Stole Himself: The Slave Odyssey of Hans Jonathan. University of Chicago Press: Chicago, USA.

Pardo-Seco, J., Heinz, T., Taboada-Echalar, P., Martinón-Torres, F., and Salas, A. 2016. Mapping the genomic mosaic of two "Afro-Bolivians" from the isolated Yungas valleys. BMC Genomics 17, 207. https://doi.org/10.1186/s12864-016-2520-x.

Patin, E., Lopez, M., Grollemund, R., Verdu, P., Harmant, C., Quach, H., Laval, G., Perry, G.H., Barreiro, L.B., Froment, A., Heyer, E., Massougbodji, A., Fortes-Lima, C., Migot-Nabias, F., Bellis, G., Dugoujon, J.-M., Pereira, J.B., Fernandes, V., Pereira, L., Van der Veen, L., Mouguiama-Daouda, P., Bustamante, C.D., Hombert, J.-M., and Quintana-Murci, L. 2017. Dispersals and genetic adaptation of Bantu-speaking populations in Africa and North America. Science 356(6337): 543-546. https://doi.org/10.1126/science.aalig88.

Pourkarim, M.R., Amini-Bavil-Olyaee, S., Kurbanov, F., Van Ranst, M., and Tacke, F. 2014. Molecular identification of hepatitis B virus genotypes/subgenotypes: revised classification hurdles and updated resolutions. World Journal of Gastroenterology: WJG 2O(23): 7152-7168. https://doi.org/10.3748/wjg.v2o.i23.7152.

Price, R. 2013a. Les Premiers Temps. La conception de l'histoire des Marrons Saamaka. Éditions Vents d'ailleurs: La Roque d'Anthéron, France.

Price, R. 2013b. Maroon Societies: Rebel Slave Communities in the Americas. Knopf Doubleday Publishing Group: New York, USA.

Price, T.D., Burton, J.H., Cucina, A., Zabala, P., Frei, R., Tykot, R.H., and Tiesler, V. 2012. Isotopic Studies of Human Skeletal Remains from a Sixteenth to Seventeenth Century AD Churchyard in Campeche, Mexico: Diet, Place of Origin, and Age. Current Anthropology 53(4): 396-433. https://doi.org/10.1086/666492.

Price, R., and Price, S. 2003. Les Marrons. Vents d'ailleurs: Serres-Castet, France.

Roblejo, H., and Marcheco-Teruel, B. 2017. Genetics and genomic medicine in Cuba. Molecular Genetics \& Genomic Medicine 5(3): 196-201. https://doi.org/10.1002/ mgg3.299.

Schablitsky, J.M., Witt, K.E., Madrigal, J.R., Ellegaard, M.R., Malhi, R.S., and Schroeder, H. 2019. Ancient DNA analysis of a nineteenth century tobacco pipe from a Maryland slave quarter. Journal of Archaeological Science 105: 11-18. https://doi.org/10.1016/ j.jas.2019.02.006.

Schlebusch, C.M., and Jakobsson, M. 2018. Tales of Human Migration, Admixture, and Selection in Africa. Annual Review of Genomics and Human Genetics 19: 405-428. https://doi.org/10.1146/annurev-genom-o83117-021759.

Schroeder, H., Ávila-Arcos, M.C., Malaspinas, A.-S., Poznik, G.D., Sandoval-Velasco, M., Carpenter, M.L., Moreno-Mayar, J.V., Sikora, M., Johnson, P.L.F., Allentoft, M.E., Samaniego, J.A., Haviser, J.B., Dee, M.W., Stafford, T.W., Jr, Salas, A., Orlando, L., Willerslev, E., Bustamante, C.D., and Gilbert, M.T.P. 2015. Genome-wide ancestry of 
17 th-century enslaved Africans from the Caribbean. Proceedings of the National Academy of Sciences of the USA 112(12):3669-3673. https://doi.org/10.1073/pnas.1421784112.

Schroeder, H., Haviser, J.B., and Price, T.D. 2014. The Zoutsteeg Three: Three New Cases of African Types of Dental Modification from Saint Martin, Dutch Caribbean: New Cases of Dental Modification from Saint Martin. International Journal of Osteoarchaeology 24(6): 688-696. https://doi.org/10.1002/oa.2253.

Schroeder, H., O'Connell, T.C., Evans, J.A., Shuler, K.A., and Hedges, R.E.M. 2009. Trans-Atlantic slavery: isotopic evidence for forced migration to Barbados. American Journal of Physical Anthropology 139(4): 547-557. https://doi.org/10.1002/ ajpa.21019.

Walker, P.L., Bathurst, R.R., Richman, R., Gjerdrum, T., and Andrushko, V.A. 20og. The causes of porotic hyperostosis and cribra orbitalia: A reappraisal of the iron-deficiency-anemia hypothesis. American Journal of Physical Anthropology 139(2): 109125. https://doi.org/10.1002/ajpa.21031.

Walvin, J. 2013. Crossings: Africa, the Americas and the Atlantic Slave Trade. Reaktion Books: Clerkenwell, UK.

Wasterlain, S.N., Neves, M.J., and Ferreira, M.T. 2016. Dental modifications in a skeletal sample of enslaved Africans found at Lagos (Portugal). International Journal of Osteoarchaeology 26(4): 621-632. https://onlinelibrary.wiley.com/doi/abs/10.1002/ oa.2453.

Zakharia, F., Basu, A., Absher, D., Assimes, T.L., Go, A.S., Hlatky, M.A., Iribarren, C., Knowles, J.W., Li, J., Narasimhan, B., Sidney, S., Southwick, A., Myers, R.M., Quertermous, T., Risch, N., and Tang, H. 20o9. Characterizing the admixed African ancestry of African Americans. Genome Biology 10(12): R141. https://doi.org/10.1186/gb-20o9 -10-12-r141. 